Article

\title{
Trends of Climate Change in Saudi Arabia: Implications on Water Resources
}

\author{
Qassem Y. Tarawneh ${ }^{1}$ and Shakhawat Chowdhury ${ }^{2, * \text { iD }}$ \\ 1 Prince Sultan Institute for Environmental, Water and Desert Research, King Saud University, \\ Riyadh 11451, Saudi Arabia; qassemtarawneh@yahoo.com \\ 2 Department of Civil and Environmental Engineering, King Fahd University of Petroleum and Minerals, \\ Water Research Group, Dhahran 31261, Saudi Arabia \\ * Correspondence: SChowdhury@kfupm.edu.sa; Tel.: +966-13-860-2560; Fax: +966-13-860-2879
}

Received: 27 December 2017; Accepted: 25 January 2018; Published: 29 January 2018

\begin{abstract}
Climate change is an important factor for sustainable water resource management in the arid and semi-arid countries. In this study, future trends of temperature and rainfall were assessed for several regions in Saudi Arabia. The linear and Mann-Kendall analyses showed an increase of temperature in all regions and decrease of rainfall in many regions. Following trend analysis, the outputs of the NCAR Community Climate System Model were obtained for three emission scenarios (high: representative concentration pathways RCP8.5; high medium: RCP6; and low: RCP2.6) for the assessment periods of 2025-2044, 2045-2064 and 2065-2084 respectively, and compared with the average values from the reference period (1986-2005). In all emission scenarios, temperature showed an increase from 1986 to 2005 in all regions. For RCP8.5, increase of temperature are in the ranges of $0.8-1.6^{\circ} \mathrm{C}, 0.9-2.7^{\circ} \mathrm{C}$ and $0.7-4.1^{\circ} \mathrm{C}$ during 2025-2044, 2045-2064 and 2065-2084 respectively. However, rainfall showed variable patterns with respect to emission scenarios and assessment periods. In most regions, the RCP6 showed decrease in rainfall from the reference period while the RCP8.5 and RCP2.6 showed variable patterns. The increase of temperature and variable pattern of rainfall may increase uncertainty in developing sustainable water resource management strategies.
\end{abstract}

Keywords: climate change; Mann-Kendall analysis; emission scenarios; increase in temperature; rainfall variation; water resource management

\section{Introduction}

Climate change is an essential component for strategic water resource management in arid and semi-arid countries, including Saudi Arabia. Using regional models, Hasanean and Almazroui [1] showed the decreasing trends of rainfall in most regions during 1978-2009 while no trend was reported for the southwest region. Chowdhury and Al-Zahrani [2] predicted an increase of rainfall by $15-25 \mathrm{~mm} /$ year in the central, western and eastern regions by 2050 while Al-Zawad [3] predicted the rainfall increase by $26-35 \mathrm{~mm} /$ year during 2070-2100. In the southwest region, Chowdhury and Al-Zahrani [2] predicted the rainfall increase of 109.7-130.4 mm/year while Al-Zawad [3] predicted an increase of $96.7 \mathrm{~mm} /$ year.

Using the linear and Mann-Kendall (M-K) trends, Rehman and Al-Hadrami [4] reported an extreme temperature trend in the west coast of Saudi Arabia. This study showed an increase in summer temperature and the number of hot days per year, due possibly to the combined effects of higher temperature and lower rainfall in this period. The mean annual maximum temperature could increase at a higher rate than the mean annual minimum temperature [4]. Almazroui [5] reported the increase of temperature by $0.65{ }^{\circ} \mathrm{C}$ per decade while the central region to the coast of the Red Sea would be affected by the increased extreme rainfall events. This study applied the regional climate model 
(PRECIS) for the predictions. Chowdhury and Al-Zahrani [2] showed an increase of temperature by 1.8-4.1 ${ }^{\circ} \mathrm{C}$ in different regions of Saudi Arabia, which was consistent to the global positive trends [6]. Addisu et al. [7] reported the extremely variable temperature and rainfall in 17 (out of 109) stations in Ethiopia where the coefficients of variation (CV) were in the range of $20-89 \%$. The multi-model ensemble combination showed an enhanced predictive capacity for climatic parameters in comparison to a single model [8].

Several studies have reported the effects of climate change on the availability and quality of water resources, increased morbidity and mortality due to thermal extremes, epidemics, malnutrition, geographical and seasonal spread of infectious vector, rodent borne diseases, and cardiovascular and respiratory illness [9-12]. In the past three decades, climate change related diseases were responsible for approximately 150,000 deaths and five million disability-adjusted life years (DALYs) [10,11]. The Intergovernmental Panel on Climate Change (IPCC) has explained the vulnerability of climate change in terms of exposure to hazards and the capacity to adapt. Understanding the interaction of climatic parameters and environment is likely to reduce vulnerability, such as growing new crops suitable to climate change and efficient management of water resources [13,14]. Increase in temperature might decrease dissolved oxygen (DO) and increase dissolved organic matter (DOM) and salinity in source water [2,15]. Past studies have reported an increase of agricultural water demand by $5-15 \%$ during 2050, which was attributed to increased evapotranspiration [2]. An increase of temperature by $1{ }^{\circ} \mathrm{C}$ might change the thermal limits of a crop by $10-30 \%$, which could push the crop over the brink and affect crop yields [16]. In addition, an increase in temperature by $1{ }^{\circ} \mathrm{C}$ might increase the capacity of air to hold water vapor by seven percent, resulting in reduced precipitation [17]. As such, the water resources and soil-water balance might be affected further. Global warming will affect rainfall and temperature, which can have effects on groundwater reserves and soil moisture [18]. Many countries have incorporated the effects of climate change for strategic water resource management.

Saudi Arabia is characterized by a semi-arid environment with high temperature variability, low annual rainfall, no natural perennial flow and limited groundwater reserves [2]. The policies on agriculture, industry and water resources are greatly affected by the climatic condition. Despite the availability of several studies on climate forecasting, comprehensive information on climatic variability and its implications is limited. This study aims to use the historical data on climatic parameters from 1985-2013 to predict the current trends for temperature and rainfall in the central, north and southwest regions of Saudi Arabia. Following trend analysis, the outputs from 14 weather stations in Saudi Arabia were obtained from the National Center for Atmospheric Research (NCAR) Community Climate System Model (CCSM4) for the periods of 2025-2044, 2045-2064 and 2065-2084 under three standard emission scenarios, known as the representative concentration pathways (RCP). The RCP were defined as: high (RCP8.5), high-medium (RCP6) and low (RCP2.6) emission scenarios. The outputs were compared with temperature and rainfall data from the reference period (1986-2005), and the change in temperature and rainfall were predicted for the periods of 2025-2044, 2045-2064 and 2065-2084 respectively. The possible implications of climatic variability on water resources were discussed.

\section{Methodology}

\subsection{Data Statistics}

In this study, the monthly data on temperature and rainfall in different regions of Saudi Arabia were obtained for the period of 1985-2013 from the Presidency of Meteorology and Environment (PME), Saudi Arabia [19]. The data from Riyadh, Tabouk and Abha weather stations, representing the central, north and southwest regions of Saudi Arabia, respectively, were selected for analysis [19]. These data were grouped into different seasons and specific months representing the cold and hot periods. The variability of data was discussed and the extreme values (e.g., outliers) were identified using the box plots. The coefficients of variation $(\mathrm{CV})$ were calculated as $\mathrm{CV}=\mathrm{std}$. $\mathrm{dev} / \mathrm{mean}$. These data were used for trend analysis using the linear and Mann-Kendall methods. 


\subsection{Trend Analysis}

Among many methods, the Mann-Kendall (M-K) test is widely used for trend analysis [19]. The $\mathrm{M}-\mathrm{K}$ test is advantageous due to its non-sensitivity to data normality (e.g., non-parametric) and the test statistics are not affected by the non-homogeneous time series. The $\mathrm{M}-\mathrm{K}$ test assumes the hypothesis, $\mathrm{H}_{0}$, indicating no trend and that the observations $\left(\mathrm{x}_{\mathrm{i}}\right)$ are randomly variable with time. The alternative hypothesis $\mathrm{H}_{1}$, indicating an increasing or decreasing monotonic trend. The test assumes time series of $n$ records and $x_{j}$ and $x_{k}$ as two subsets of data where $k=1,2,3, \ldots, n-1$; and $j=k+1, k+2, k+3$, $\ldots, n$. The data are evaluated as a time series in sequence. Each value in the dataset is compared with all of the subsequent data points. If the value in the later period is higher than the earlier period, the $\mathrm{M}-\mathrm{K}$ statistics, $S$ is decremented by 1 . If it is lower, $S$ will be decremented by -1 . Following the $\mathrm{M}-\mathrm{K}$ test, final value of $S$ can be computed as:

$$
\begin{gathered}
S=\sum_{\mathrm{k}=1}^{n-1} \sum_{\mathrm{j}=\mathrm{k}+1}^{n} \operatorname{Sgn}\left(\mathrm{x}_{\mathrm{j}}-\mathrm{x}_{\mathrm{k}}\right) \\
S=\operatorname{Sgn}\left(\mathrm{x}_{\mathrm{j}}-\mathrm{x}_{\mathrm{k}}\right)=\left\{\begin{array}{ll}
+1 & \text { if } \mathrm{x}_{\mathrm{j}}-\mathrm{x}_{\mathrm{k}}>0 \\
0 & \text { if } \mathrm{x}_{\mathrm{j}}-\mathrm{x}_{\mathrm{k}}=0 \\
-1 & \text { if } \mathrm{x}_{\mathrm{j}}-\mathrm{x}_{\mathrm{k}}<0
\end{array}\right\}
\end{gathered}
$$

where $x_{j}$ and $x_{k}$ are used as the annual or monthly values and/or $j$ and $k, j>k_{r}$ respectively. A high positive value of $S$ indicates an increasing trend while a low negative value indicates a decreasing trend. If $n \geq 10, S$ is considered normally distributed with variance as:

$$
\sigma^{2}=\operatorname{VAR}(S)=\frac{1}{18}\left[n(n-1)(2 n+5)-\sum_{\mathrm{p}=1}^{\mathrm{q}} \mathrm{t}_{\mathrm{p}}\left(\mathrm{t}_{\mathrm{p}}-1\right)\left(2 \mathrm{t}_{\mathrm{p}}+5\right)\right]
$$

where $n=$ number of data points; $\mathrm{q}=$ number of tied groups; and $\mathrm{t}_{\mathrm{p}}=$ number data values in group $\mathrm{p}$. Consequently, the standardized $Z$ statistics follows the normal standard distribution as:

$$
Z=\left\{\begin{array}{cc}
\frac{S-1}{\sqrt{\operatorname{VAR}(S)}} & \text { if } S>0 \\
0 & \text { if } S=0 \\
\frac{S+1}{\sqrt{\operatorname{VAR}(S)}} & \text { if } S<0
\end{array}\right\}
$$

The trend is computed using the $Z$ value. The positive and negative values of $Z$ indicate the increasing and decreasing trends respectively. For the non-parametric test, the Kendall's tau $(\tau)$ assess the statistical associations based on the ranks of the data. The Kendall's tau for two sets of data can be determined as:

$$
\operatorname{Tau}(\tau)=\frac{\text { (Number of concordant pairs }- \text { Number of discordant pairs })}{n(n-1) / 2}
$$

The value of $\tau$ varies between -1 and +1 representing a strong negative association to strong positive association between the data sets.

The linear and sequential version of $\mathrm{M}-\mathrm{K}$ trends $(\mathrm{U}(t)$ and $\hat{\mathrm{U}}(t))$ were investigated. The $\mathrm{U}(t)$ and $\hat{\mathrm{U}}(t)$ demonstrate the change of trend with time. This test considers the relative values of all terms in a time series $\left(x_{1}, x_{2}, \ldots, x_{n}\right)$. The magnitudes of $x_{j}$ annual mean time series $(j=1,2,3, \ldots, n)$ are compared with $x_{k}(k=1,2, \ldots, j-1)$. At each comparison, the number of cases $x_{j}>x_{k}$ is counted and denoted by $n_{\mathrm{j}}$. The test statistics $(t)$ are computed as:

$$
t=\sum_{i=1}^{n} n_{\mathrm{i}}
$$


The mean and variance of $t$ is calculated as:

$$
\begin{gathered}
E(t)=\frac{n(n-1)}{4} \\
\operatorname{Var}(t)=\frac{n(n-1)(2 n+5)}{72}
\end{gathered}
$$

The sequential values of the statistics (Û) are calculated as

$$
\mathrm{U}(t)=\frac{(t-E(t))}{\sqrt{\operatorname{Var}(t)}}
$$

Similarly, values of $\hat{U}(t)$ are computed backward starting from the end of the series. The sequential version of the Mann-Kendall could be considered as an effective way of locating the beginning year(s) of a trend. The $\mathrm{M}-\mathrm{K}$ statistics, $\mathrm{U}(t)$ is a value that indicates direction (or sign) and statistical magnitude of a trend in a series. When $\mathrm{U}(t)$ is significant at the $5 \%$ level, it can be decided whether it is an increasing or a decreasing trend depending on whether $\mathrm{U}(t)>0.0$ or $\mathrm{U}(t)<0.0$.

\subsection{NCAR Community Climate System Model (CCSM4) Data}

The Community Climate Model (CCM) was developed by the National Center for Atmospheric Research (NCAR) in 1983. The CCM has been improved to the Community Climate System Model (CCSM), which is a coupled climate model system for simulating the Earth's climate. In CCSM, the earth's atmosphere, ocean, land surface and sea-ice, and one central coupler component are simulated concurrently, which assists in explaining the earth's past, present and future climate. It allows the downscaling of climatic information following the dynamic and statistical approaches $[20,21]$. The details on downscaling can be found in [21].

In 2008, a total of 20 modeling groups and the World Climate Research Programs (WCRP) Working Group on Coupled Modelling agreed to promote a new set of coordinated climate model experiments with the inputs from the Analysis, Integration and Modeling of the Earth System (AIMES) project of the International Geosphere-Biosphere Programme (IGBP). These experiments represented the fifth phase of the Couple Model Inter-comparison Project (CMIP5). The CMIP5 was involved in the modeling of long-term (century scale) integration and decadal prediction, or near-term integration (10-30 years) [22-24]. In CMIP5, the long-term simulation was coupled with the biogeochemical components that accounted for the fluxes of carbon between the ocean, atmosphere and terrestrial biosphere carbon reservoirs. The spatial resolution for the atmospheric and ocean components were in the ranges of $0.5-4.0^{\circ}$ and $0.2-2.0^{\circ}$ respectively. The CCSM4 model was simulated for the RCP8.5, RCP6 and RCP2.6 emission scenarios. The output data on temperature and rainfall were recorded. The data on temperature and rainfall in the central, north, southwest, eastern and western regions of Saudi Arabia were analyzed for the periods of 2025-2044, 2045-2064 and 2065-2084 respectively. These data were compared with the reference period (1986-2005). The weather stations were located in five regions: central (Riyadh, Unaizah); north (Hail, Al-Jouf and Tabouk); southwest (Abha, Al-Baha and Jazan); eastern (Dammam and Al-Hofuf); and western (Jeddah, Taif, Makkah and Al-Madinah) respectively [19]. Further details on the model and outputs can be found in Figure 1 and from the NCAR Community Climate System Model (CCSM4) web portal. 




Figure 1. Locations of 14 weather stations in Saudi Arabia included in the current study. The arrows in red and blue colors show the wind directions in summer and winter respectively. Central region (Riyadh, Unaizah); North region (Hail, Al-Jouf and Tabouk); Southwest region (Abha, Al-Baha and Jazan); Eastern region (Dammam and Al-Hofuf); and Western region (Jeddah, Taif, Makkah and Al-Madinah).

\section{Results and Discussion}

\subsection{Statistical Analysis}

\subsubsection{Temperature}

\section{Central Region}

The seasonal variability of temperature in Riyadh, Tabouk and Abha representing the central, north and southwest regions are shown in Table 1 . The data are presented for mean temperature in 
four seasons: winter (December, January and February), spring (March, April and May), summer (June, July and August) and autumn (September, October and November). In addition, the data in January and June are summarized to explain the cold and hot months respectively (Table 1). The mean temperature in summer was 2.4 times the mean temperature in winter $\left(35.5^{\circ} \mathrm{C}\right.$ and $15{ }^{\circ} \mathrm{C}$ respectively), which is characterized as continental climate. The mean temperature in spring and autumn were similar $\left(26.2^{\circ} \mathrm{C}\right.$ and $26.6^{\circ} \mathrm{C}$ respectively). The mean and median were similar in each season while skewness and kurtosis were small (Table 1). Skewness measures of the lack of symmetry of data while kurtosis indicates whether the data are heavy-tailed or light-tailed relative to a normal distribution. The negative and positive skewness indicated that the data were skewed toward left and right respectively (Table 1). In addition, CV were low (range: 0.020-0.107). The similar mean, median, low skewness, kurtosis and CV indicated the normal distributions (Table 1). The box plots (Figure 2) show the percentile distributions of data where the bottom and top of the boxes represent the first quartile (25-percentile) and the third quartile (75-percentile) respectively. The lower and upper fringes represent the lowest and highest limits of the data respectively. Any data beyond this limit is an outlier, such as $12.6^{\circ} \mathrm{C}$ for winter (Figure $2 \mathrm{a}$ ), representing an extreme low mean temperature.

Table 1. Seasonal variability of mean temperature in the central (Riyadh), north (Tabouk) and southwest (Abha) regions of Saudi Arabia.

\begin{tabular}{|c|c|c|c|c|c|c|c|c|}
\hline \multicolumn{9}{|c|}{ Central Region (Riyadh) } \\
\hline Element & Mean & Max. & Min. & Median & Skewness & Kurtosis & Std. Dev & CV \\
\hline Winter & 15 & 16.6 & 12.6 & 15.1 & -1.02 & 0.97 & 0.97 & 0.07 \\
\hline Spring & 26.2 & 27.7 & 24.1 & 26.2 & -0.39 & -0.58 & 0.92 & 0.04 \\
\hline Summer & 35.5 & 36.8 & 33.8 & 35.6 & -0.16 & -0.24 & 0.71 & 0.02 \\
\hline Autumn & 26.6 & 27.8 & 25.7 & 26.6 & 0.58 & -0.02 & 0.58 & 0.02 \\
\hline January & 13.5 & 15.9 & 10.2 & 13.7 & -0.35 & -0.09 & 1.45 & 0.11 \\
\hline June & 34.7 & 36.2 & 33.1 & 34.7 & -0.21 & -0.56 & 0.84 & 0.02 \\
\hline \multicolumn{9}{|c|}{ North Region (Tabouk) } \\
\hline Winter & 12.2 & 15.2 & 8.9 & 12.3 & -0.38 & 2.56 & 1.14 & 0.09 \\
\hline Spring & 22.2 & 24.2 & 20.2 & 22.1 & 0.15 & 0.78 & 0.86 & 0.04 \\
\hline Summer & 31 & 33 & 29.5 & 31.1 & 0.14 & 0.15 & 0.81 & 0.03 \\
\hline Autumn & 23.5 & 25.8 & 22.3 & 23.3 & 0.09 & 1.65 & 0.76 & 0.03 \\
\hline January & 10.9 & 14.9 & 7.4 & 10.9 & -0.03 & 0.61 & 1.6 & 0.15 \\
\hline June & 30.04 & 31.7 & 28.9 & 29.9 & 0.54 & 0.08 & 0.69 & 0.02 \\
\hline \multicolumn{9}{|c|}{ Southwest Region (Abha) } \\
\hline Winter & 19.4 & 22.1 & 15.5 & 19.8 & -0.61 & 0.07 & 1.58 & 0.08 \\
\hline Spring & 18.3 & 21.5 & 12.8 & 24.2 & -0.55 & 1.7 & 1.7 & 0.09 \\
\hline Summer & 24.3 & 27.3 & 18.8 & 24.6 & -0.64 & 0.55 & 1.8 & 0.07 \\
\hline Autumn & 19.4 & 21.4 & 16.8 & 19.7 & -0.39 & -0.71 & 1.2 & 0.06 \\
\hline January & 12.5 & 15.1 & 10 & 12.5 & -0.07 & -0.57 & 1.23 & 0.10 \\
\hline June & 23.6 & 27.3 & 16 & 24.4 & -1.5 & 2.27 & 2.8 & 0.12 \\
\hline
\end{tabular}

$\mathrm{CV}$ : Coefficient of variation.

\section{North Region}

The summer mean temperature $\left(31^{\circ} \mathrm{C}\right)$ was almost 2.5 times the winter mean temperature $\left(12.2^{\circ} \mathrm{C}\right.$ ), indicating the continental climate (Table 1). The skewness were small (range: $\left.-0.38-0.54\right)$ while standard deviation (range: 0.69-1.6) and CV (range: 0.023-0.147) were low (Table 1), indicating the normal distributions. Figure $2 \mathrm{e}-\mathrm{h}$ shows that the fourth quartile temperature in winter were in the range of $13-13.2^{\circ} \mathrm{C}$ (e.g., highest) while the first quartile temperature were in the range of $9.8-11.6^{\circ} \mathrm{C}$ (Figure 2e). Two outliers for the highest $\left(15.2{ }^{\circ} \mathrm{C}\right)$ and lowest $\left(9{ }^{\circ} \mathrm{C}\right)$ were noted. In summer, the 
fourth quartile temperature was in the range of $31.5-32.2^{\circ} \mathrm{C}$ with the maximum of $33^{\circ} \mathrm{C}$ (Figure $2 \mathrm{~g}$ ). In autumn, approximately $50 \%$ data were in the range of $23-23.9{ }^{\circ} \mathrm{C}$ (Figure $2 \mathrm{~h}$ ).



Figure 2. Box plots of mean temperature for different seasons in Riyadh, Tabouk and Abha representing the central, north and southwest regions of Saudi Arabia. (a-d) winter, spring, summer and autumn in Riyadh respectively. (e-h) winter, spring, summer and autumn in Tabouk respectively. (i-1) winter, spring, summer and autumn in Abha respectively. Bottom and top of the boxes represent the first quartile (Q1) and the third quartile (Q3) respectively. The lower whisker extends up to $(\mathrm{Q} 1-1.5 \times(\mathrm{Q} 3-\mathrm{Q} 1))$ and upper whisker extends up to $(\mathrm{Q} 3+1.5 \times(\mathrm{Q} 3-\mathrm{Q} 1))$. The horizontal lines within the box represent the medians of the data. Values larger than Q3 or smaller than Q1 by at least 1.5 times the interquartile range (IQR) are outliers. The $(+)$ sign indicates the mean values of the data.

\section{Southwest Region}

The southwest region was different from the central and north regions. In the southwest region, mean values in summer and winter were $24.3^{\circ} \mathrm{C}$ and $19.4{ }^{\circ} \mathrm{C}$ (Table 1) respectively. The intra-seasonal difference was less than $5{ }^{\circ} \mathrm{C}$ while in the central and north regions, the differences were up to $20^{\circ} \mathrm{C}$ (Table 1). The wet summer was likely to reduce the temperature difference in the southwest 
region while the other regions had very low rainfall in summer. The data had low skewness and low CV (range: 0.062-0.119), and the mean and median were similar in most seasons (except spring) (Table 1), indicating the normal distributions of data. In summer, the range of the first to third quartiles (50\% data) were $22.9^{\circ} \mathrm{C}$ to $25.4{ }^{\circ} \mathrm{C}$ (Figure $2 \mathrm{k}$ ) while in winter, the range was $12.3-13.9^{\circ} \mathrm{C}$ (Figure 2i). The winter temperature in the southwest was higher than the central and north regions, due mainly to the effects of the moist air mass from the Red Sea in the equatorial side. The central and north regions were affected by the dry continental air mass from the Siberian high system in winter. Overall temperature was lower in the southwest region due to the effects of elevation, while the other regions were affected by tropical air mass in spring, summer and autumn. Further details on temperature distributions can be found in Figure 2i-l.

\subsubsection{Rainfall}

The rainfall showed spatial and temporal variability, which was irregular, torrential and often associated with thunderstorms [1]. In the southwest, rainfall was often affected by the wet summer monsoon. The mean rainfall in the central, north and southwest regions were 106.9, 31.7 and $206 \mathrm{~mm} /$ year respectively and the ranges were 32-309.4, 1.1-89.2 and 87.4-568.2 mm/year respectively (Table 2). The lower rainfall in the central and north regions indicated the aridity in these regions (Table 2). The skewness were in the range of 0.84-1.6 indicating the distributions with right tails. The higher values of skewness and CV indicated non-normal distributions of rainfall (Table 2). Figure 3 shows that $50 \%$ data in the central region were in the range of $65-111 \mathrm{~mm} /$ year. The fourth quartile data were in the range of $111-168 \mathrm{~mm} /$ year and the outlier was $309 \mathrm{~mm} /$ year. In the north region, $50 \%$ data had the range of $11-45 \mathrm{~mm}$ /year and the fourth quartile data were in the range of $45-89 \mathrm{~mm}$ /year. In the southwest, $50 \%$ data had the range of $125-252 \mathrm{~mm} /$ year while the fourth quartile data were in the range of $252-413 \mathrm{~mm} /$ year. The extreme value ( $568 \mathrm{~mm} /$ year) was an outlier (Figure 3).

Table 2. Summary of rainfall in the central (Riyadh), north (Tabouk) and southwest (Abha) regions of Saudi Arabia.

\begin{tabular}{ccccccccc}
\hline Element & Mean & Max. & Min. & Median & Skew & Kur & St. Dev & CV \\
\hline Central region (Riyadh) & 106.9 & 309.4 & 32 & 86 & 1.6 & 2.02 & 68.5 & 0.64 \\
North region (Tabouk) & 31.7 & 89.2 & 1.1 & 28 & 0.84 & 0.01 & 24 & 0.76 \\
Southwest region (Abha) & 206 & 568.2 & 87.4 & 179 & 1.5 & 2.3 & 115.9 & 0.56 \\
\hline
\end{tabular}



(a)

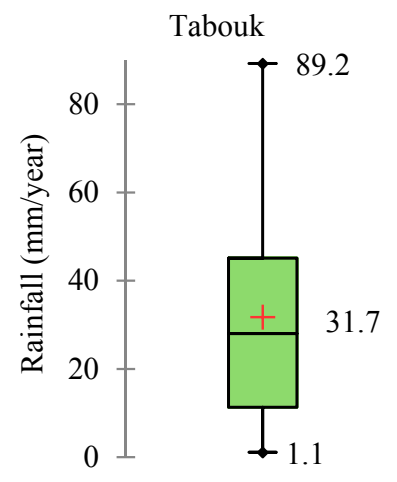

(b)



(c)

Figure 3. Box plots of rainfall for Riyadh (a), Tabouk (b) and Abha (c) representing the central, north and southwest regions. Bottom and top of the boxes represent the first quartile (Q1) and the third quartile (Q3) respectively. The lower whisker extends up to $(\mathrm{Q} 1-1.5 \times(\mathrm{Q} 3-\mathrm{Q} 1))$ and upper whisker extends up to $(\mathrm{Q} 3+1.5 \times(\mathrm{Q} 3-\mathrm{Q} 1))$. The horizontal lines within the box represent the medians of the data. Values larger than Q3 or smaller than Q1 by at least 1.5 times the interquartile range (IQR) are outliers. The $(+)$ sign indicates the mean values of the data. 


\subsection{Trend Analysis}

\subsubsection{Temperature}

The $\mathrm{M}-\mathrm{K}$ trends were analyzed for annual mean temperature, and minimum and maximum temperature in January and June for Riyadh, Tabouk and Abha representing the central, north and southwest regions respectively. The parameters are shown in Table 3 . The $p$-value $\leq 0.05$ indicated the support toward rejection of $\mathrm{H}_{0}$ and acceptance of $\mathrm{H}_{1}$, indicating the presence of trend. The positive values of Kendall's tau $(\tau)$ showed an increasing trend while the negative values showed a decreasing trend. The high positive value of $S$ statistic indicated an increasing trend while the low negative value indicated a decreasing trend. In Riyadh, temperature showed increasing trends in most scenarios except the maximum temperature in January (Table 3). In Tabouk, the M-K test showed increasing trends for annual mean temperature and minimum temperature in June, while no trend was observed for the other data. In Abha, the M-K test showed increasing trends in all cases except the maximum temperature in January (Table 3).

Table 3. Mann-Kendall trend analysis of temperature and rainfall for Riyadh, Tabouk and Abha representing the central, north and southwest regions of Saudi Arabia.

\begin{tabular}{|c|c|c|c|c|c|c|}
\hline \multicolumn{7}{|c|}{ Riyadh } \\
\hline Element & $\begin{array}{l}\text { Mann-Kendall } \\
\text { Statistic (S) }\end{array}$ & $\begin{array}{c}\text { Kendall's } \\
\text { Tau }\end{array}$ & Var. $\left(\sigma^{2}\right)$ & $p$-Value & Alpha & Test Interpretation \\
\hline Annual Mean Temp. & 142 & 0.37 & 0 & 0.005 & 0.05 & Reject $\mathrm{H}_{0} /$ Trend. \\
\hline January Min. Temp. & 118 & 0.69 & 2838 & 0.028 & 0.05 & Reject $\mathrm{H}_{0} /$ Trend. \\
\hline January Max. Temp. & 62 & 0.15 & 2838 & 0.252 & 0.05 & Accept $\mathrm{H}_{0} /$ No Trend. \\
\hline January Min. Temp. & 278 & 0.69 & 2833 & $<0.0001$ & 0.05 & Reject $\mathrm{H}_{0} /$ Trend. \\
\hline January Max. Temp. & 149 & 0.37 & 2827 & 0.005 & 0.05 & Reject $\mathrm{H}_{0} /$ Trend. \\
\hline Rainfall & -35 & -0.08 & 0 & 0.567 & 0.05 & Accept $\mathrm{H}_{0} /$ No Trend. \\
\hline \multicolumn{7}{|c|}{ Tabouk } \\
\hline Annual Mean Temp. & 174 & 0.44 & 0 & 0.001 & 0.05 & Reject $\mathrm{H}_{0} /$ Trend. \\
\hline January Min. Temp. & 21 & 0.05 & 3133 & 0.721 & 0.05 & Accept $\mathrm{H}_{0} ;$ No Trend. \\
\hline January Max. Temp. & 11 & 0.03 & 3131 & 0.858 & 0.05 & Accept $\mathrm{H}_{0}$; No Trend. \\
\hline June Min. Temp. & 247 & 0.57 & 3130 & $<0.0001$ & 0.05 & Reject $\mathrm{H}_{0} /$ Trend. \\
\hline June Max. Temp. & 77 & 0.18 & 3114 & 0.173 & 0.05 & Accept $\mathrm{H}_{0}$; No Trend. \\
\hline Rainfall & -33 & -0.08 & 0 & 0.572 & 0.05 & Accept $\mathrm{H}_{0}$; No Trend. \\
\hline \multicolumn{7}{|c|}{ Abha } \\
\hline Annual Mean Temp. & 393 & 0 & 0 & $<0.0001$ & 0.05 & Reject $\mathrm{H}_{0} /$ Trend. \\
\hline January Min. Temp. & 260 & 0.44 & 4951.3 & 0 & 0.05 & Reject $\mathrm{H}_{0} /$ Trend. \\
\hline January Max. Temp. & 20 & 0.03 & 4948.6 & 0.787 & 0.05 & Accept $\mathrm{H}_{0}$; No Trend. \\
\hline Junuary Min. Temp. & 265 & 0.44 & 4949.6 & 0 & 0.05 & Reject $\mathrm{H}_{0} /$ Trend. \\
\hline Junuary Max. Temp. & 186 & 0.31 & 4951.3 & 0.009 & 0.05 & Reject $\mathrm{H}_{0} /$ Trend. \\
\hline Rainfall & -157 & -0.36 & 0 & 0.005 & 0.05 & Reject $\mathrm{H}_{0} /$ Trend. \\
\hline
\end{tabular}

The linear trends for the winter and summer mean temperature are shown Figure 4. In Riyadh, Tabouk and Abha, the data showed increasing trends in both winter and summer seasons (Figure 4). In all regions, the rates of increase of temperature were higher in summer than winter. In Riyadh, averages of temperature in summer and winter during $1985-1989$ were $33.54{ }^{\circ} \mathrm{C}$ and $12.96{ }^{\circ} \mathrm{C}$ respectively. During 2009-2013, the averages were $35.4{ }^{\circ} \mathrm{C}$ and $14.6{ }^{\circ} \mathrm{C}$ respectively. During this period, increase of temperature in summer and winter were $1.86^{\circ} \mathrm{C}$ and $1.64{ }^{\circ} \mathrm{C}$ respectively. The linear rates of increase during summer and winter were $0.0676{ }^{\circ} \mathrm{C} /$ year and $0.0561^{\circ} \mathrm{C} /$ year respectively (Figure 4). In Tabouk, averages of temperature in summer and winter during $1984-1988$ were $30.6{ }^{\circ} \mathrm{C}$ and $12.6^{\circ} \mathrm{C}$ respectively. During 2009-2013, the averages were $31.9^{\circ} \mathrm{C}$ and $13.4^{\circ} \mathrm{C}$ respectively. The linear rates of increase of temperature during summer and winter were $0.0583{ }^{\circ} \mathrm{C} /$ year and $0.0427{ }^{\circ} \mathrm{C} /$ year respectively (Figure 4). In Abha, averages of temperature in summer and winter during 1975-1979 were $21.9{ }^{\circ} \mathrm{C}$ and $13.2{ }^{\circ} \mathrm{C}$ respectively. During $2005-2009$, the averages were $25.5^{\circ} \mathrm{C}$ and $14.3^{\circ} \mathrm{C}$ 
respectively. The linear rates of increase of temperature during summer and winter were $0.125^{\circ} \mathrm{C} /$ year and $0.0662{ }^{\circ} \mathrm{C} /$ year respectively. Overall, the rates of increase of temperature in summer and winter were in the ranges of $0.0583-0.125^{\circ} \mathrm{C} /$ year and $0.0427-0.0662{ }^{\circ} \mathrm{C} /$ year respectively. The higher rates of increase of summer temperature were consistent to past study [4]. Almazroui [5] reported that the average rate of increase of temperature was $0.65^{\circ} \mathrm{C}$ per decade, which was consistent to the current findings. The higher rates of temperature increase during summer deserve further attention.

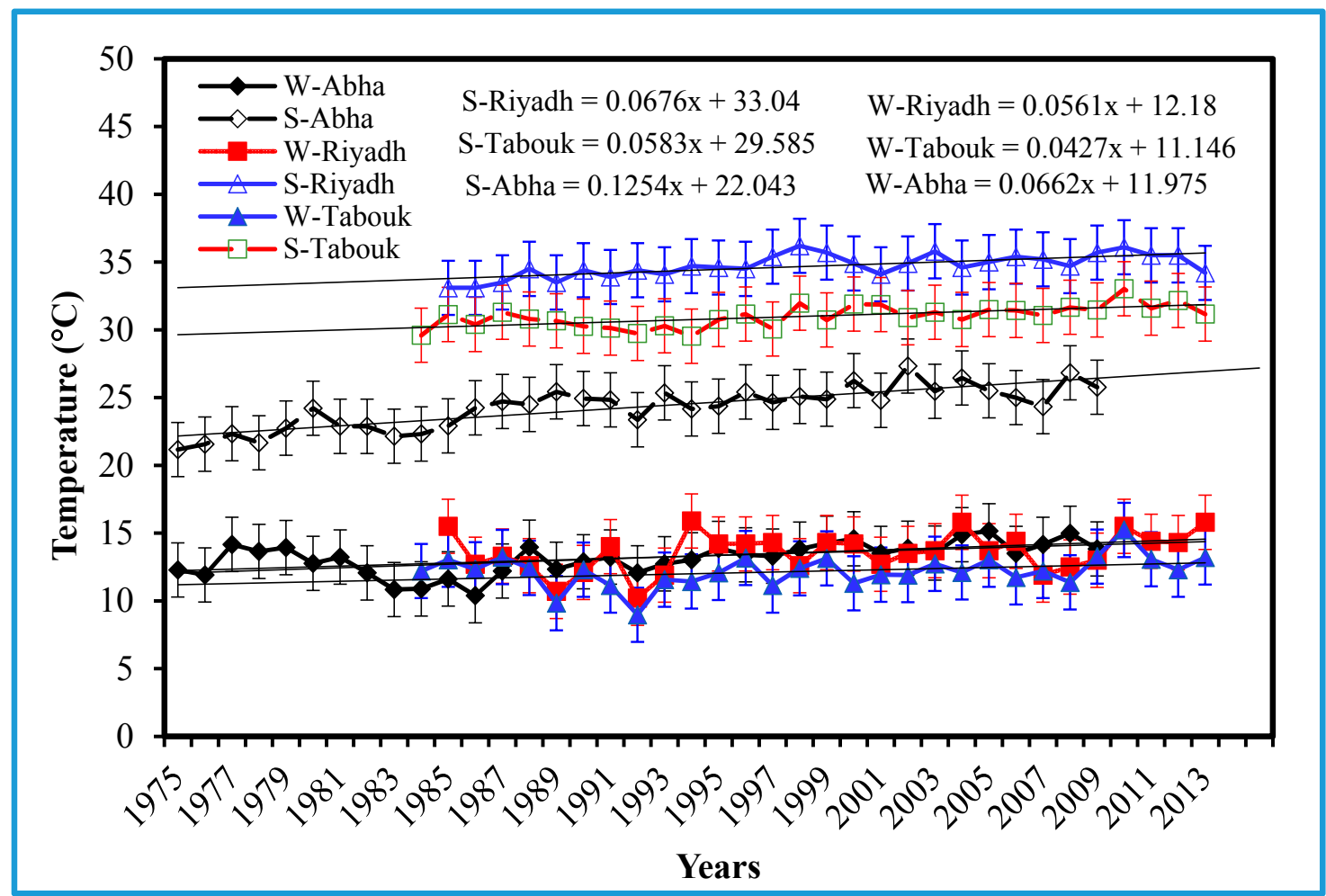

Figure 4. Linear trends of mean temperature in winter $(\mathrm{W})$ and summer $(\mathrm{S})$ for Riyadh, Tabouk and Abha representing the central, north and southwest regions (1984-2013); S-Riyadh: summer for Riyadh; W-Riyadh: winter for Riyadh; S-Tabouk: summer for Tabouk; W-Tabouk: winter for Tabouk; S-Abha: summer for Abha; W-Abha: winter for Abha.

\subsubsection{Rainfall}

The future trends were assessed for the annual rainfall in Riyadh, Tabouk and Abha. The data did not show any trend in the central and north regions (Table 3) and were supported by the low Kendall's tau ( -0.075 and -0.076 respectively). The southwest region showed decreasing trend ( $p$-value $=0.005)$, which was also supported by the large negative $S(S=-157)$ and negative Kendall's tau (-0.361) (Table 3). The linear and sequential version of $\mathrm{M}-\mathrm{K}$ trends ( $\mathrm{U}$ and $\hat{\mathrm{U}}$ ) for Riyadh, Tabouk and Abha are shown in Figure 5a-f. In Riyadh, no consistent trend was observed (Figure 5a) with increasing trend during 1992-1997 and 2006-2010, and decreasing trends during 1985-1992 and 2010-2015 (Figure 5a,b). In Tabouk, no consistent trend was also observed with decreasing trend during 1985-2003 and increasing trend during 2004-2015 (Figure 5c,d). The rainfall in Abha (southwest region) showed an overall decreasing trend (Figure 5e). The sequential plot (Figure 5f) showed an increasing trend during 1988-1997 and 2004-2005. However, during 1998-2003, 2006-2009 and 2010-2012, rainfall showed decreasing trends. Overall, multiple trends were observed in all regions during the data periods. However, the overall rainfall in Abha has been reduced in the recent years and was also evidenced by the reduction in the natural vegetation [25]. 




(a)



(c)

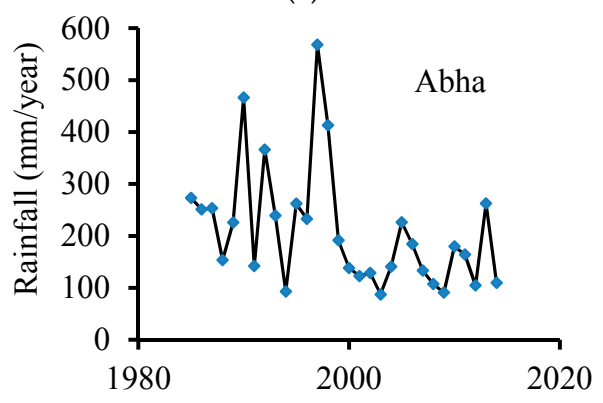

(e)

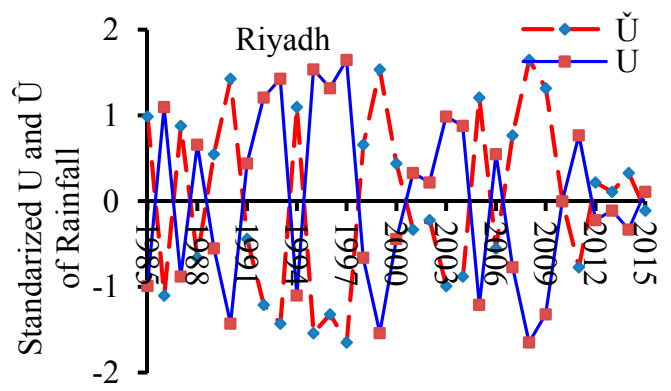

(b)

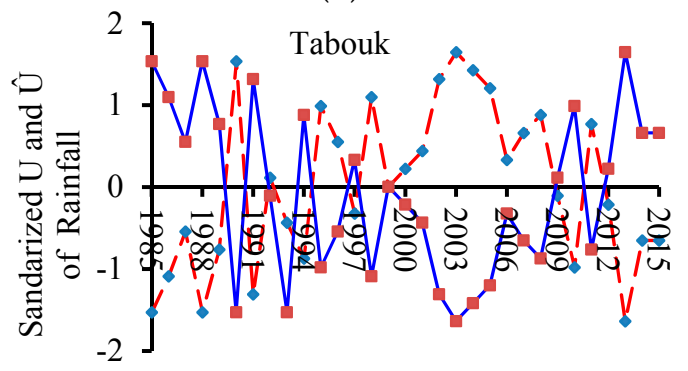

(d)

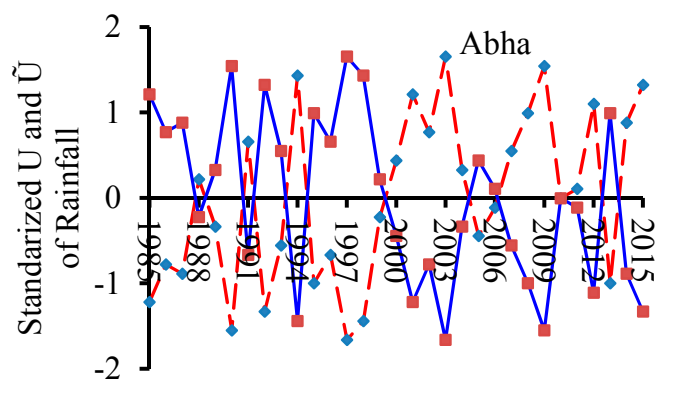

(f)

Figure 5. Linear trends (left) and the sequential version of the Mann-Kendall trends (right) of the mean annual rainfall for the central $(\mathbf{a}, \mathbf{b})$, north $(\mathbf{c}, \mathbf{d})$ and southwest (e,f) regions (1985-2013). U(t) and $\hat{U}(t)$ are the sequential M-K statistics, computed through forward and backward starting of the time series data.

\subsection{Climate Change Prediction}

The predictions of the CCSM4 model have been adopted by the 5th Assessment Report of the IPCC. The output data of temperature and rainfall were obtained for 14 weather stations under RCP8.5, RCP6 and RCP2.6 emission scenarios for the periods of 2025-2044, 2045-2064 and 2065-2084 respectively. The change of temperature and rainfall were compared with the averages in the reference period (1986-2005). The 14 weather stations are located in five regions: central (Riyadh and Unaizah); north (Tabouk, Al-Jouf and Taif); southwest (Abha, Al-Baha and Jazan); eastern (Dammam and Al-Hofuf); and western (Makkah, Jeddah, Taif and Madinah) regions. The latitude and longitude of the stations are shown in Table 4. The location map can also be found in the Presidency of Meteorology and Environment (PME), Saudi Arabia website [19]. The changes of temperature and rainfall in these five regions were investigated. 
Table 4. Change in rainfall (mm/year) during 2025-2044, 2045-2064 and 2065-2084 from the reference period (1986-2005).

\begin{tabular}{|c|c|c|c|c|c|c|c|c|c|c|c|c|c|}
\hline \multirow[b]{2}{*}{ Region } & \multirow[b]{2}{*}{ Stations } & \multirow[b]{2}{*}{ Lat. } & \multirow[b]{2}{*}{ Lon. } & \multirow[b]{2}{*}{ Elevation (m) } & \multicolumn{3}{|c|}{ 2025-2044 } & \multicolumn{3}{|c|}{ 2045-2064 } & \multicolumn{3}{|c|}{ 2065-2084 } \\
\hline & & & & & RCP8.5 & RCP6.0 & RCP2.6 & RCP8.5 & RCP6.0 & RCP2.6 & RCP8.5 & RCP6.0 & RCP2.6 \\
\hline \multirow{2}{*}{ Central } & Riyadh & 24.7 & 46.67 & 564 & 7.6 & -10.2 & 5.1 & 5.1 & -5.1 & -7.6 & 0 & 0 & 5.1 \\
\hline & Unaizah & 26.08 & 43.96 & 746 & 12.7 & -10.2 & 5.1 & 20.3 & 0 & -2.5 & 7.6 & 10.2 & 5.1 \\
\hline \multirow{3}{*}{ North } & Hail & 27.5 & 41.72 & 1010 & 12.7 & -2.5 & 10.2 & 15.2 & 5.1 & -5.1 & -2.5 & 15.2 & 7.6 \\
\hline & Al-Jouf & 29.87 & 40.1 & 560 & 7.6 & 0 & 7.6 & 12.7 & 0 & -5.1 & -2.5 & 5.1 & 2.5 \\
\hline & Tabouk & 28.38 & 36.56 & 737 & 5.1 & -2.5 & 10.2 & 12.7 & 5.1 & -5.1 & -2.5 & 10.2 & 10.2 \\
\hline \multirow{3}{*}{ Southwest } & Abha & 18.24 & 42.51 & 2600 & -10.2 & -33 & 20.3 & 12.7 & 10.2 & 5.1 & 43.2 & -5.1 & -7.6 \\
\hline & Al-Baha & 19.99 & 41.47 & 2200 & 5.1 & -22.9 & 20.3 & 48.3 & -20.3 & -27.9 & 48.3 & 10.2 & 2.5 \\
\hline & Jazan & 16.86 & 42.57 & 350 & 25.4 & 12.7 & 38.1 & 111.8 & 25.4 & -22.9 & 152.4 & 63.5 & 27.9 \\
\hline \multirow{2}{*}{ Eastern } & Dammam & 26.37 & 49.97 & 50 & 17.8 & 0 & 12.7 & 2.5 & -2.5 & -5.1 & 5.1 & 20.3 & 10.2 \\
\hline & Al-Hofuf & 25.33 & 49.61 & 160 & 12.7 & -7.6 & 12.7 & 30.5 & -35.6 & -38.1 & 0 & 0 & 5.1 \\
\hline \multirow{4}{*}{ Western } & Jeddah & 21.18 & 39.21 & 17 & 7.6 & -10.2 & 10.2 & 40.6 & -7.6 & -17.8 & 30.5 & 17.8 & 5.1 \\
\hline & Taif & 21.41 & 40.52 & 1530 & 0 & -15.2 & 2.5 & 27.9 & -17.8 & -27.8 & 25.4 & 7.6 & -2.5 \\
\hline & Makkah & 21.37 & 39.86 & 331 & 7.6 & -10.2 & 10.2 & 40.6 & -7.6 & -17.8 & 30.5 & 17.8 & 5.1 \\
\hline & Al-Madinah & 24.51 & 39.56 & 849 & 10.2 & -7.6 & 12.7 & 22.9 & -5.1 & -2.5 & 12.7 & 12.7 & 17.8 \\
\hline
\end{tabular}




\subsubsection{Temperature}

\section{Central Region}

Figure 6 shows the temperature increase from 1986 to 2005. The central region is represented by two stations: Riyadh and Unaizah (Figure 6a). Increase in temperature during 2025-2044, 2045-2064 and 2065-2084 are in the ranges of $1.2-1.6{ }^{\circ} \mathrm{C}, 1.3-2.6{ }^{\circ} \mathrm{C}$ and $1.2-4.1^{\circ} \mathrm{C}$ respectively (Figure 6a). In RCP8.5, increase in temperature during 2065-2084 are in the range of 3.9-4.1 ${ }^{\circ} \mathrm{C}$. In 2025-2044 and 2045-2064, these are $1.6^{\circ} \mathrm{C}$ and $2.6^{\circ} \mathrm{C}$ respectively (Figure 6a). In RCP8.5 and RCP6, increase in temperature was minimum in 2025-2044 and maximum in 2065-2084 respectively. However, in RCP2.6, increase in temperature was maximum during 2045-2064. The variability under RCP2.6 may be due to the interaction effects of rainfall, temperature and the flow of cold/warm wind.

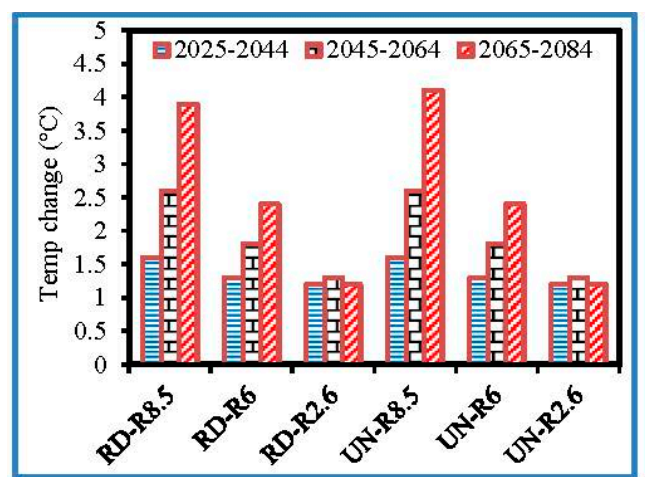

(a) Central region

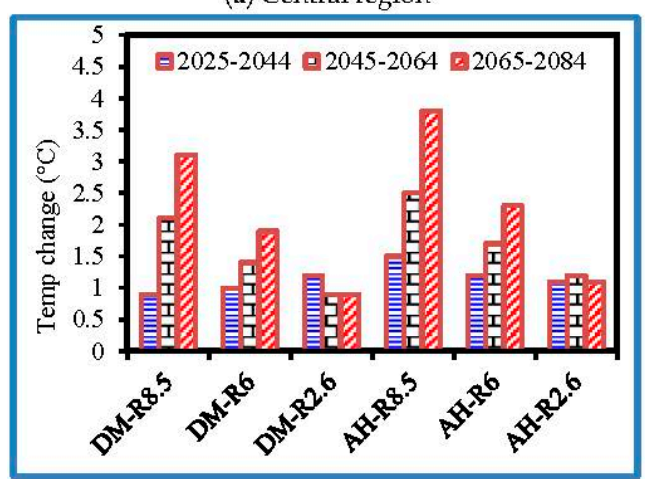

(d) Eastern region

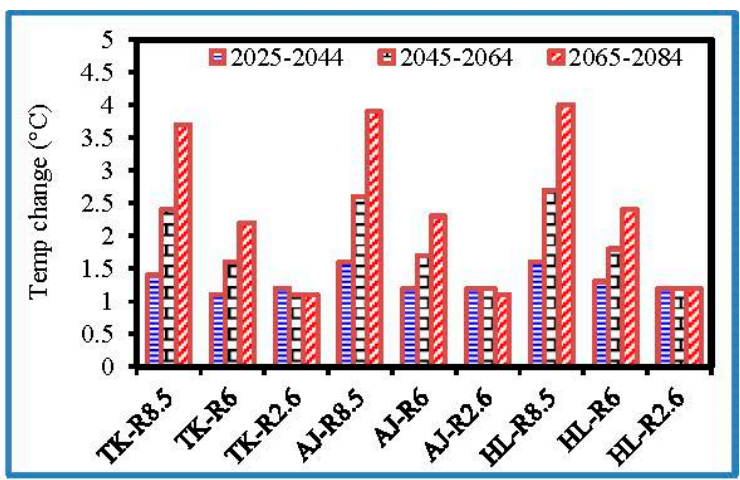

(b) North region

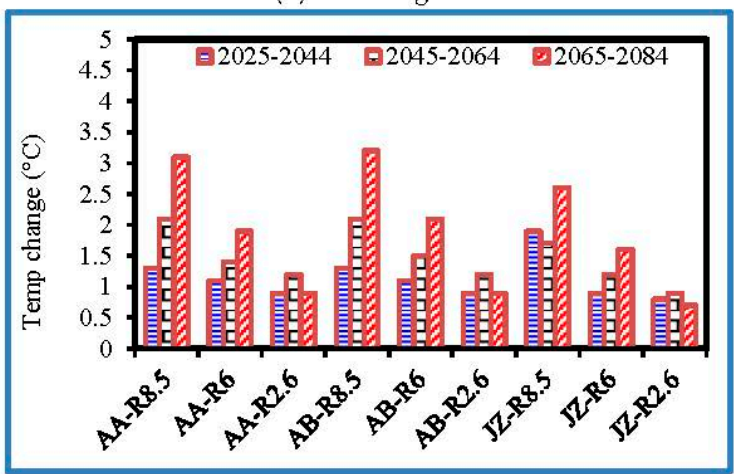

(c) Southwest region

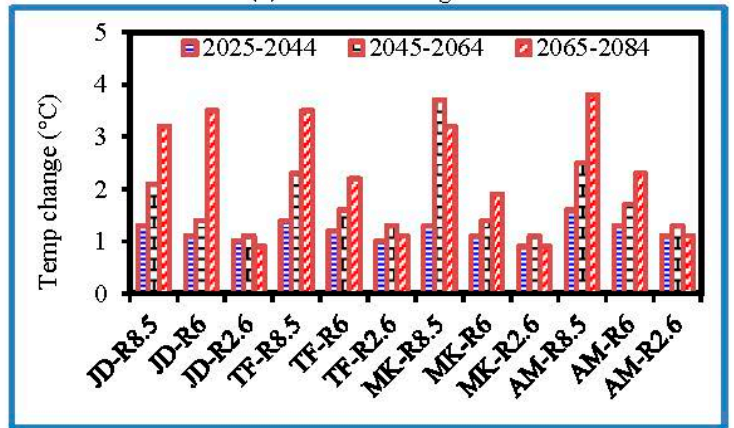

(e) Western region

Figure 6. Prediction of temperature change with respect to the reference period (1986-2005). (a) Central region; (b) North region; (c) Southwest region; (d) Eastern region; (e) Western region; RD: Riyadh; UN: Unaizah; TK: Tabouk; AJ: Al-Jouf; HL: Hail; AA: Abha; AB: Al-Baha; JZ: Jazan; DM: Dammam; AH: Al-Hofuf; JD: Jeddah; TF: Taif; MK: Makkah; AM: Al-Madinah; R8.5: RCP8.5 (High emission scenario); R6: RCP6 (High-medium emission scenario); R2.6: RCP2.6 (Low emission scenario). 


\section{North Region}

The north region is represented by the stations in Tabouk, Al-Jouf and Hail. Increase of temperature during $2025-2044,2045-2064$ and $2065-2084$ are in the ranges of $1.1-1.6^{\circ} \mathrm{C}, 1.1-2.7^{\circ} \mathrm{C}$ and $1.1-4.0^{\circ} \mathrm{C}$ respectively (Figure 6b). In RCP8.5, increase in temperature during 2025-2044, 2045-2064 and 2065-2084 are in the ranges of $1.4-1.6^{\circ} \mathrm{C}, 2.4-2.7^{\circ} \mathrm{C}$ and $3.7-4.0^{\circ} \mathrm{C}$ respectively (Figure $6 \mathrm{~b}$ ). In RCP6, increase in temperature during these periods are in the ranges of $1.1-1.3^{\circ} \mathrm{C}, 1.6-1.8^{\circ} \mathrm{C}$ and $2.2-2.4^{\circ} \mathrm{C}$ respectively while in $\mathrm{RCP} 2.6$, these are $1.2{ }^{\circ} \mathrm{C}, 1.1-1.2{ }^{\circ} \mathrm{C}$ and $1.1-1.2{ }^{\circ} \mathrm{C}$ respectively (Figure 6b). In RCP2.6, increase in temperature during 2025-2044 were equal to or higher than 2045-2064 and 2065-2084 respectively (Figure 6b).

\section{Southwest Region}

The southwest region is represented by the stations in Abha, Al-Baha and Jazan. Increase of temperature during 2025-2044, 2045-2064 and 2065-2084 are in the ranges of $0.8-1.9^{\circ} \mathrm{C}, 0.9-2.1^{\circ} \mathrm{C}$ and $0.7-3.2^{\circ} \mathrm{C}$ respectively (Figure 6c). In RCP8.5, increase in temperature during 2025-2044, 2045-2064 and 2065-2084 are in the ranges of $1.3-1.9^{\circ} \mathrm{C}, 1.7-2.1^{\circ} \mathrm{C}$ and $2.6-3.2^{\circ} \mathrm{C}$ respectively (Figure 6c). In RCP6, increase in temperature during these periods are in the ranges of $0.9-1.1^{\circ} \mathrm{C}, 1.2-1.5^{\circ} \mathrm{C}$ and $1.6-2.1^{\circ} \mathrm{C}$ respectively while in RCP2.6, these values are $0.8-0.9^{\circ} \mathrm{C}, 0.9-1.2^{\circ} \mathrm{C}$ and $0.7-0.9^{\circ} \mathrm{C}$ respectively (Figure 6c). In RCP2.6, increase in temperature during 2045-2064 were higher than 2025-2044 and 2065-2084 respectively (Figure 6c).

\section{Eastern Region}

The eastern region is represented by the stations in Dammam and Al-Hofuf. In all emission scenarios, increase of temperature during 2025-2044, 2045-2064 and 2065-2084 are in the ranges of $0.9-1.5^{\circ} \mathrm{C}, 0.9-2.5^{\circ} \mathrm{C}$ and $0.7-3.8^{\circ} \mathrm{C}$ respectively (Figure 6d). In RCP8.5, increase in temperature during $2025-2044,2045-2064$ and $2065-2084$ are in the ranges of $0.9-1.5^{\circ} \mathrm{C}, 2.1-2.5^{\circ} \mathrm{C}$ and $3.1-3.8^{\circ} \mathrm{C}$ respectively (Figure 6d). In RCP6, increase in temperature during these periods are in the ranges of $1.0-1.2^{\circ} \mathrm{C}, 1.4-1.7^{\circ} \mathrm{C}$ and $1.9-2.3^{\circ} \mathrm{C}$ respectively while in $\mathrm{RCP} 2.6$, these values are $1.1-1.2^{\circ} \mathrm{C}, 0.9-1.2^{\circ} \mathrm{C}$ and $0.9-1.1^{\circ} \mathrm{C}$ respectively (Figure $6 \mathrm{~d}$ ). In RCP8.5 and RCP6 scenarios, increase in temperature are in the order of 2025-2044 < 2045-2064 < 2065-2084 while the RCP2.6 scenario showed variable findings (Figure 6d).

\section{Western Region}

The western region is represented by the stations in Jeddah, Taif, Makkah and Al-Madinah. In all emission scenarios, temperature increase during 2025-2044, 2045-2064 and 2065-2084 are in the ranges of $0.9-1.6^{\circ} \mathrm{C}, 1.1-3.7^{\circ} \mathrm{C}$ and $0.9-3.8^{\circ} \mathrm{C}$ respectively (Figure 6e). In RCP8.5, increase in temperature during $2025-2044,2045-2064$ and $2065-2084$ are in the ranges of $1.3-1.6^{\circ} \mathrm{C}, 2.1-3.7^{\circ} \mathrm{C}$ and $3.2-3.8^{\circ} \mathrm{C}$ respectively (Figure 6e). In RCP6, increase in temperature during these periods are in the ranges of $1.1-1.3^{\circ} \mathrm{C}, 1.4-1.7^{\circ} \mathrm{C}$ and $1.9-3.5^{\circ} \mathrm{C}$ respectively, while in RCP2.6, these values are $0.9-1.1^{\circ} \mathrm{C}$, $1.1-1.3^{\circ} \mathrm{C}$ and $0.9-1.1^{\circ} \mathrm{C}$ respectively (Figure 6e). In RCP2.6, all stations showed higher increase in temperature during 2045-2064 than 2025-2044 and 2065-2084 respectively (Figure 6e).

Overall, increase in temperature during $2025-2044$ are in the ranges of $0.9-1.9^{\circ} \mathrm{C}, 0.9-1.3^{\circ} \mathrm{C}$ and $0.8-1.2^{\circ} \mathrm{C}$ for the RCP8.5, RCP6 and RCP2.6 scenarios respectively. During 2045-2064, the ranges of temperature increase are $1.7-3.7^{\circ} \mathrm{C}, 1.2-1.8^{\circ} \mathrm{C}$ and $0.9-1.3^{\circ} \mathrm{C}$ respectively under these scenarios while in 2065-2084, these are $2.6-4.1^{\circ} \mathrm{C}, 1.6-3.5^{\circ} \mathrm{C}$ and $0.7-1.2^{\circ} \mathrm{C}$ respectively. Increase in temperature in the central, north, southwest, eastern and western regions are in the ranges of $1.2-4.1^{\circ} \mathrm{C}, 1.1-4.0^{\circ} \mathrm{C}$, 0.7-3.8 ${ }^{\circ} \mathrm{C}, 0.9-3.1^{\circ} \mathrm{C}$ and $0.9-3.8^{\circ} \mathrm{C}$ respectively. In all regions, RCP 8.5 and RCP6.0 showed consistent patterns while RCP2.6 showed the variable patterns. 


\subsubsection{Rainfall}

\section{Central Region}

The change of rainfall during 2025-2044, 2045-2064 and 2065-2084 from the reference period (1986-2005) are shown in Table 4. In RCP8.5, change of rainfall during 2025-2044, 2045-2064 and 2065-2084 are in the ranges of 7.6-12.7, 5.1-20.3 and 0-7.6 mm/year respectively. In RCP6, the data showed a decrease in rainfall during 2025-2044 and 2045-2064, and an increase in 2065-2084. In RCP2.6, the data showed increase in rainfall during 2025-2044 and 2065-2084, and decrease in 2045-2064. However, overall change of rainfall is likely to be insignificant $(-10.2-20.3 \mathrm{~mm} /$ year).

\section{North Region}

In RCP8.5, change in rainfall during 2025-2044, 2045-2064 and 2065-2084 are in the ranges of $5.1-12.7,12.7-15.2$ and $-2.5 \mathrm{~mm} /$ year respectively. In RCP6, the data showed a decrease in rainfall during 2025-2044 (-2.5-0 mm/year), and an increase during 2045-2064 and 2065-2084 (0-5.1 and $5.1-15.2 \mathrm{~mm} /$ year respectively). In RCP2.6, the data showed an increase in rainfall during 2025-2044 and 2065-2084, and a decrease in 2045-2064. The overall change in rainfall is likely to be insignificant (-5.1-15.2 mm/year). The central and north regions showed similar patterns on the change of rainfall.

\section{Southwest Region}

In RCP8.5, change in rainfall during 2025-2044, 2045-2064 and 2065-2084 are in the ranges of -10.2-25.4, 12.7-111.8 and 43.2-152.4 mm/year respectively. In RCP6 and RCP2.6, the data showed variable patterns in different stations (Table 4). In RCP8.5, Al-Baha and Jazan showed an increase in rainfall by 5.1-48.3 and 25.4-152.4 mm/year during 2025 through 2084. In RCP6, rainfall in Jazan is likely to increase by $12.7-63.5 \mathrm{~mm}$ /year. The rainfall data in Abha and Al-Baha indicated variable patterns while in Jazan, rainfall is likely to increase with time (Table 4).

\section{Eastern Region}

In RCP8.5, change in rainfall during 2025-2044, 2045-2064 and 2065-2084 are in the ranges of 12.7-17.8, 2.5-30.5 and 0.0-5.1 mm/year respectively. In RCP6, the data showed a decrease in rainfall during 2025-2044 (-7.6-0.0 mm/year) and 2045-2064 (-35.6-2.5 mm/year), and an increase in 2065-2084 (0-20.3 mm/year). In RCP2.6, the data showed an increase in rainfall during 2025-2044 and 2065-2084, and decrease in 2045-2064. The overall change is likely to be $-38.1-30.5 \mathrm{~mm} /$ year.

\section{Western Region}

In RCP8.5, change in rainfall during 2025-2044, 2045-2064 and 2065-2084 are in the ranges of $0-10.2,22.9-40.6$ and $12.7-30.5 \mathrm{~mm} /$ year respectively. In RCP6, the data showed a decrease in rainfall during 2025-2044 (-15.2--7.6 mm/year) and 2045-2064 (-17.8--5.1), and an increase in 2065-2084 (7.6-17.8 mm/year). In RCP2.6, the data showed variable patterns in different periods (Table 4).

Overall, the highest increase of rainfall was predicted for Jazan (southwest) by $152.4 \mathrm{~mm} /$ year during 2065-2084 under RCP8.5. The RCP6 showed the decrease in rainfall in most stations during 2025-2044 and 2045-2064, and increase in 2065-2084 (Table 4). In RCP2.6, all stations showed increase in rainfall from the reference period except Abha (southwest) and Taif (western) during 2065-2084. Rainfall in Abha and Taif are likely to be reduced by $7.65 \mathrm{~mm} /$ year and $2.5 \mathrm{~mm} /$ year respectively. The data showed significant variability among the regions, which needs better understanding for water resource management. It is to be noted that the CCSM4 model was simulated based on the single valued parameters for the RCP8.5, RCP6 and RCP2.6 emission scenarios while the parameters were likely to have uncertainty. While the study presented the averages of temperature and rainfall under the low, medium and high emission scenarios, tempo-spatial variability of input parameters could impart significant uncertainty to the output data. As such, the forecasted temperature and rainfall are 
likely to have a range instead of single values. Upon availability of more reliable output data in future, the comparison with the reference period can be updated in future.

\section{Implications on Water Resources and Quality}

Three emission scenarios were investigated for temperature and rainfall change during 2025-2044, 2045-2064 and 2065-2084. The increase in temperature can vary in the ranges of $0.8-1.9^{\circ} \mathrm{C}, 0.9-3.7^{\circ} \mathrm{C}$ and $0.7-4.1^{\circ} \mathrm{C}$ respectively. The changes in rainfall can be in the ranges of $-33-38.1,-38.1-111.8$ and $-7.6-152.4 \mathrm{~mm} /$ year respectively. The increase in temperature and variable patterns of rainfall can have consequences on water resources, water quality, agricultural productions and agricultural water demand.

Increase in temperature is likely to increase evaporation from the open reservoirs. In Saudi Arabia, there are 449 dams to collect, store and recharge runoff and to control flash floods [26]. These dams are often used as potential sources for drinking water. The southern part has the valley basins, which often dry up due to higher evaporation, excessive use of water and low precipitation [26-28]. Past studies reported an approximately 50\% increase in evaporation between 2011 and 2050 [2]. Few studies have reported that the free surface evaporation from wadies in Saudi Arabia could be in the range of 5-80\% of water on annual basis $[25,27]$. For a dam reservoir in the southwestern region, loss through surface evaporation was reported to be in the range of 4.7-6.0 $\mathrm{m}$ per year [28]. Missimer et al. [28] reported that up to $80 \%$ of water could be lost in old wadies through evaporation. Increase in temperature is likely to increase the evaporative loss from the dam reservoirs and affect the water sources. Future study should investigate the extent of such effects. In addition, an increase in temperature by $1^{\circ} \mathrm{C}$ and $5{ }^{\circ} \mathrm{C}$ may reduce surface runoff by 115-184 million $\mathrm{m}^{3}$ (MCM) and 600-960 MCM per year respectively [29,30]. The recharge of water to all aquifers was estimated to reduce by 91.4 MCM and $475 \mathrm{MCM}$ per year due to $1^{\circ} \mathrm{C}$ and $5{ }^{\circ} \mathrm{C}$ increase in temperature respectively. The overall reduction in water sources was estimated to be 241-1435 MCM per year [29,30]. Other studies reported the possible increase in agricultural water demand by 5-15\% in 2050 for the unchanged level of productions [2,31-33].

Increase in temperature is likely to increase the domestic water demand. In Phoenix, Arizona, increase in temperature by $1{ }^{\circ} \mathrm{C}$ was reported to increase domestic water demand by 6.7\% [34]. Using a similar rate, domestic water demand in different regions were estimated to increase by $5.4-12.7 \%$, 6.0-24.8\% and 4.7-27.5\% during 2025-2044, 2045-2064 and 2065-2084 respectively. Upon availability of the effects of temperature on domestic water demand in Saudi Arabia, the assessment can be updated further. Future study should investigate the effects of temperature increase in Saudi Arabia. In addition, quality of water in the drinking water sources are likely to be degraded with the increase of temperature [2,30,31].

The outliers in Figure 3 demonstrate occasional intense rainfall events in the central, north and southwest regions. These rainfall events are likely to generate a significant amount of surface runoff, which can recharge the groundwater aquifers [32,33]. In addition, the runoff can be collected and used for other purposes (e.g., domestic, agricultural uses). In Saudi Arabia, occasional intense rainfall events have caused several flash floods in the past, which were responsible for the loss of lives and properties [35-37]. There is a need to better protect lives and properties during flash floods from the extreme rainfall events. Future study should assess the flood hazard, runoff collection potential and aquifer recharge from such events. The increase in temperature and variable pattern of rainfall are likely to increase uncertainty on the available water resources [37-39]. Through a study in Scotland, Afzal et al. [39] demonstrated the decrease in the time-based and volumetric reliability of reservoirs under the assumption of an unchanging demand. The variability of rainfall had the greatest effect on reservoir reliability. In addition, increase in water demand could reduce reservoir reliability [39]. In Saudi Arabia, domestic water demands are likely to increase in future while the demands are highly variable in Makkah and Al-Madinah, which are very high during four months (Arabic months: Ramadan through Dhu Al-Hijjah). The decline in reliability of water 
resources necessitates careful planning for water demand satisfaction under the highly variable demand characteristics in Saudi Arabia.

\section{Conclusions}

This study presented the trends of temperature and rainfall in the central, north and southwestern regions of Saudi Arabia based on the historical data. The change in temperature and rainfall were predicted for the periods of 2025-2044, 2045-2064 and 2065-2084 using the data from the National Center for Atmospheric Research (NCAR) Community Climate System Model (CCSM4). Temperature was predicted to increase in all regions throughout 2025-2084 with the highest increase in the central and north regions while rainfall showed variable patterns with significant increase in the southwest and western regions. The regional variability of temperature increase and rainfall are significant, indicating the need for region-specific action plans to minimize the effects of climate change. In the context of water resource management, inclusion of such variability is important. Further, consumption of water in different sectors (e.g., domestic, industrial and agriculture) are likely to be affected by climate change. The quality of water in the sources (e.g., groundwater, seawater used for desalination, etc.) can be affected, which may increase treatment costs. Future study is essential to explain the extent of such effects on groundwater resources, groundwater and seawater quality, and cost of water treatment and desalination. The implications of climate change on water treatment, supply cost and human health risks deserve further attention. Despite several limitations, this study sheds light on the possible changes of temperature and rainfall in different regions of Saudi Arabia and the implications on water resource management.

Acknowledgments: The authors would like to acknowledge the support provided by the Deanship of Scientific Research (DSR) at King Fahd University of Petroleum \& Minerals (KFUPM) for funding this work through project No. RG1410-1 \& 2 .

Author Contributions: Qassem Y. Tarawneh has compiled the climatic data from the CCSM4 model outputs and performed the analysis for trends and comparison with the reference period. Shakhawat Chowdhury has compiled the results, methodology, written the manuscript and compared the findings with historical aspects. Shakhawat Chowdhury has also investigated the effects on climate change on water resources. The work was performed as a part of a research project at the King Fahd University of Petroleum and Minerals, Dhahran, Saudi Arabia.

Conflicts of Interest: The authors declare no conflicts of interest.

\section{References}

1. Hasanean, H.; Almazroui, M. Rainfall: Features and Variations over Saudi Arabia, A Review. Climate 2015, 3, 578-626. [CrossRef]

2. Chowdhury, S.; Al-Zahrani, M. Implications of Climate Change on Water Resources in Saudi Arabia. Arab. J. Sci. Eng. 2013, 38, 1959-1971. [CrossRef]

3. Al-Zawad, F.M. Impacts of climate change on water resources in Saudi Arabia. In Proceedings of the 3rd International Conference on Water Resources and Arid Environments and the 1st Arab Water Forum, Riyadh, Saudi Arabia, 16-19 November 2008.

4. Rehman, S.; Al-Hadhrmi, L.M. Extreme Temperature Trend on the West Coast of Saudi Arabia. Atmos. Clim. Sci. 2012, 2, 352-361. [CrossRef]

5. Almazroui, M. Simultaion of present and future climate of Saudi Arabia using a regional model (PRECIS). Int. J. Climatol. 2013, 33, 2247-2259. [CrossRef]

6. IPCC (Intergovernmental Panel on Climate Change). Climate change. In The IPCC Second Assessment Report; Houghton, J.T., Meira Filho, L.G., Callander, B.A., Harris, N., Kattenberg, A., Maskell, K., Eds.; Cambridge University Press: New York, NY, USA, 1996.

7. Addisu, S.; Selassie, Y.G.; Fissha, G.; Gedif, B. Time series trend analysis of temperature and rainfall in lake Tana Sub-Basin, Ethiopia. Environ. Syst. Res. 2015, 4, 1-12. [CrossRef]

8. Weigel, A.P.; Liniger, M.A.; Appenzeller, C. Can multi-model combination really enhance the prediction skill of probabilistic ensemble forecasts? Q. J. R. Meteorol. Soc. 2008, 134, 241-260. [CrossRef] 
9. IPCC (Intergovernmental Panel on Climate Change). Data Distribution Centre. 2006. Available online: http:/ / www.mad.zmaw.de/IPCC_DDC/html/SRES_TAR/index.html (accessed on 20 November 2010).

10. WHO (World Health Organization). Climate Change and Human Health-Risk and Responses, WHO Summary Report; WHO: Geneva, Switzerland, 2002.

11. Patz, J.A.; Lendrum, D.C.; Holloway, T.; Foley, J.A. Impact of regional climate change on human health. Nature 2005, 438, 310-317. [CrossRef] [PubMed]

12. UNOCHA (United Nations Office for the Coordination of Humanitarian Affairs). Climatic Change and Human Vulnerability; UNOCHA: Zeneva, Switzerland, 2008.

13. IPCC (Intergovernmental Panel on Climate Change). Climate Change: Third Assessment Report of the Intergovernmental Panel on Climate Change; Cambridge University Press: Cambridge, UK, 2001.

14. DeNicola, E.; Aburizaiza, O.S.; Siddique, A.; Khwaja, H.; Carpenter, M.D. Climate Change and Water Scarcity: The Case of Saudi Arabia. Ann. Glob. Health 2015, 81, 342-353. [CrossRef] [PubMed]

15. Rajab, R.; Prudhomme, C. Climate Change on Water Resources Management in Arid and Semi-arid Regions: Prospective and Challenges for the 21st Century. Biosyst. Eng. 2002, 81, 3-34.

16. Parry, M.L.; Swaminathan, M.S. Effect of climatic change on food production. In Confronting Climatic Change: Risks, Implications, and Responses; Mintzer, I.M., Ed.; Cambridge University Press: Cambridge, UK, 1993; Chapter 8.

17. Trenberth, K.E. Changes in precipitation with climate change. Clim. Res. 2011, 47, 123-138. [CrossRef]

18. Kang, Y.; Khan, S.; Maa, X. Climate change impacts on crop yield, crop water productivity and food security-A review. Progress Nat. Sci. 2009, 19, 1665-1674. [CrossRef]

19. PME (Presidency of Meteorology and Environment), Saudi Arabia. 2017. Available online: https://www. pme.gov.sa/En/Weather/LocalWeatherInfo/Pages/stationinfo.aspx (accessed on 29 January 2018).

20. Mann, H.B. Non-parametric test against trend. Econometrica 1945, 13, 245-259. [CrossRef]

21. Fowler, H.J.; Blenkinsop, S.; Tebaldi, C. Review linking climate change modeling to impacts studies recent advances in downscaling techniques for hydrological modeling. Int. J. Climatol. 2007, 27, 1547-1578. [CrossRef]

22. NCAR Community Climate System Model. Downscaling procedure. Statistical Downscaling of the Community Climate System Model-Monthly Temperature and Precipitation Projections. Hoar, T., Nychka, D., Eds.; 2008. Available online: http:/ / gisclimatechange.ucar.edu/ (accessed on 27 November 2012).

23. Hibbard, K.A.; Meehl, G.A.; Cox, P.M.; Friedlingstein, P. A strategy for climate change stabilization experiments. Eos 2007, 88, 217-221. [CrossRef]

24. Meehl, G.A.; Hibbard, K.A. A Strategy for Climate Change Stabilization Experiments with AOGCMS and ESMS; WCRP (World Climate Research Programme) Informal Report; WCRP: Aspen, CO, USA, 2006.

25. Claussen, M.; Mysak, L.A.; Weaver, A.J.; Crucifix, M.; Fichefet, T.; Loutre, M.F.; Weber, S.L.; Alcamo, J.; Alexeev, V.A.; Berger, A.; et al. Earth system models of intermediate complexity: Closing the gap in the spectrum of climate system models. Clim. Dyn. 2002, 18, 579-586.

26. MEWA (Ministry of Environment, Water and Agriculture). Annual Report. Riyadh, Saudi Arabia, 2017. Available online: https:/ / www.mewa.gov.sa/en/Pages/default.aspx (accessed on 27 December 2017).

27. Lopez, O.; Stenchikov, G.; Missimer, T.M. Water management during climate change using aquifer storage and recovery of stormwater in a dunefield in western Saudi Arabia. Environ. Res. Lett. 2014, 9, 075008. [CrossRef]

28. Missimer, T.M.; Drewes, J.E.; Amy, G.; Maliva, R.G.; Keller, S. Restoration of wadi aquifers by artificial recharge with treated wastewater. Groundwater 2012, 50, 514-527. [CrossRef] [PubMed]

29. Abderrahman, W.A.; Al-Harazin, I.M. Assessment of climate changes on water resources in the Kingdom of Saudi Arabia. In Proceedings of the GCC Environment and Sustainable Development Symposium, Dhahran, Saudi Arabia, 28-30 January 2008; pp. D-1-1-D-1-13.

30. Chowdhury, S.; Al-Zahrani, M. Reuse of Treated Wastewater in Saudi Arabia: An Assessment Framework. J. Water Reuse Desalin. 2013, 3, 297-314. [CrossRef]

31. Alkolibi, F.M. Possible effects of global warming on agriculture and Water resources in Saudi Arabia: Impacts and responses. Clim. Chang. 2002, 54, 225-245. [CrossRef]

32. AL-Sheikh, A.A.; Tarawneh, Q.Y. An analysis of Dry Spell Patterns Intensity and Duration in Saudi Arabia. Middle East J. Sci. Res. 2013, 13, 314-327. 
33. Subyani, A.M. Hydrochemical identification and salinity problem of ground water in Wadi Yalamlam basin, Western Saudi Arabia. J. Arid Environ. 2005, 60, 53-66. [CrossRef]

34. Balling, R.C., Jr.; Gober, P. Climate Variability and Residential Water Use in the City of Phoenix, Arizona. J. Appl. Meteorol. Climatol. 2007, 46, 1130-1137. [CrossRef]

35. Arab News. Flash Flood Fury Leaves 7 Dead in South. Published in Arab News on Monday, 5 August 2013. Available online: http:/ / www.arabnews.com/news / 460295 (accessed on 30 September 2013).

36. BBC News. 2009. Available online: http://news.bbc.co.uk/2/hi/8384832.stm (accessed on 30 November 2010).

37. Al-Zahrani, M.; Chowdhury, S.; Abo-Monasar, A. Augmentation of surface water sources from spatially distributed rainfall in Saudi Arabia. J. Water Reuse Desalin. 2015, 5, 391-406. [CrossRef]

38. Afzal, M.; Gagnon, A.S.; Mansell, M.G. Changes in the variability and periodicity of precipitation in Scotland. Theor. Appl. Climatol. 2015, 119, 135-159. [CrossRef]

39. Afzal, M.; Gagnon, A.S.; Mansell, M.G. The impact of projected changes in climate variability on the reliability of surface water supply in Scotland. Water Sci. Technol. Water Supply 2015, 15, 736-745. [CrossRef]

(C) 2018 by the authors. Licensee MDPI, Basel, Switzerland. This article is an open access article distributed under the terms and conditions of the Creative Commons Attribution (CC BY) license (http://creativecommons.org/licenses/by/4.0/). 